\title{
Trade Openness, Foreign Direct Investment and Sustainable Agriculture in Africa
}

\section{Otwartość handlu, bezpośrednie inwestycje zagraniczne i zrównoważone rolnictwo w Afryce}

\section{Ping Ju*, Muhammad Khalid Anser**, Romanus Osabohien ${ }^{\star \star *}$, Onyinye Ochuba ${ }^{\star \star \star *}$, Rolle Remi Ahuru ${ }^{\star * * *}$, Junaid Ashraf ${ }^{\star * * * *}$}

\author{
${ }^{*}$ Fuzhou University of International Studies and Trade, \\ Research Center of Open Economics and Trade, Fuzhou, China \\ ${ }^{* *}$ Xi'an University of Architecture and Technology, School of Public Administration, China \\ E-mail:khalidsnnu@yahoo.com \\ ${ }^{\star * *}$ Covenant University, Department of Economics \& Development Studies, Ota, Nigeria \\ Covenant University, Centre for Economics \& Development Studies, Ota, Nigeria \\ E-mails (Corresponding author): romanus.osabohien@covenantuniversity.edu.ng, \\ romik247@gmail.com \\ ${ }^{* \star * \star}$ University of Africa, Department of Economics, Toru Orua, Bayelsa State, Nigeria \\ E-mail: onyinye.ochuba@uat.edu.ng,daluochuba@gmail.com \\ ${ }^{* \star * * *}$ University of Benin, Department of Economics, Benin, Nigeria \\ University of Benin, Centre of Excellence in Reproductive Health Innovation, Benin, Nigeria \\ E-mail: remi.rolle@cerhi.uniben.edu \\ $\star * * * * *$ Jiangxi University of Finance and Economics, School of Statistics, \\ Nanchang, Jiangxi, China \\ E-mail: junaidashraf2020@outlook.com
}

\begin{abstract}
This study applied a panel data of 37 African countries in examining the impact of trade openness and foreign direct investment on sustainable agriculture towards the attainment of the United Nation (UN) Sustainable Development Goals (SDGs), especially, SDG-2, with the aim of ending extreme hunger, achieve food security and improve nutrition and promote sustainable agriculture. Data for the study was sourced from the Country Policy and Institutional Assessment (CPIA) and World Development Indicators (WDI) of the World Bank, for the period 2005 - 2019. To control for endogeneity, the study engaged the system Generalised Method of Moments (GMM). The result shows that FDI and trade openness have significant negative impact on agricultural sustainability in Africa. This result implies that, increase in FDI may decrease agricultural sustainability by $0.00294 \%$, while increase in trade openness may lower agricultural sustainability by $0.430066 \%$. Therefore, the study concludes that while trade openness is negative, policy to raise local production towards export promotion should be encouraged. In addition, FDI should be encouraged to augment local employment and investment towards increasing output and productivity in the Africa region.
\end{abstract}

Key words: agriculture, sustainability, trade liberalisation, sustainable development 


\section{Streszczenie}

W artykule wykorzystano dane panelowe z 37 krajów afrykańskich w badaniu wpływu otwartości handlu i bezpośrednich inwestycji zagranicznych na zrównoważone rolnictwo i osiągnięcie Celów zrównoważonego rozwoju ONZ, zwłaszcza SDG-2, który ma za zadanie wyeliminowanie skrajnego głodu, osiągniecie bezpieczeństwa żywnościowego oraz promowanie zrównoważonego rolnictwa. Dane do badania pochodzą z Country Policy and Institutional Assessment (CPIA) oraz World Development Indicators (WDI) Banku Światowego i obejmują lata 2005-2019. W celu kontroli endogeniczności w badaniu wykorzystano system Generalized Method of Moments (GMM). Wyniki pokazują, że Bezpośrednie Inwestycje Zagraniczne (FDI) i otwartość handlu mają znaczący negatywny wpływ na zrównoważony rozwój rolnictwa w Afryce. Wynik ten implikuje, że wzrost FDI może obniżyć zrównoważenie rolnictwa o 0,00294\%, podczas gdy wzrost otwartości handlu może obniżyć zrównoważenie rolnictwa o 0,430066 \%. Z tego wynika, że chociaż otwartość handlu jest negatywna, należy zachęcać do polityki zwiększania produkcji lokalnej w kierunku promocji eksportu. Ponadto należy zachęcać do FDI w celu zwiększenia lokalnego zatrudnienia i inwestycji w celu zwiększenia produkcji i produktywności w Afryce.

Słowa kluczowe: rolnictwo, zrównoważoność, liberalizacja handlu, rozwój zrównoważony

\section{Introduction}

Developing countries, especially Africa, have over the years witnessed a continuous inflow of economic resources from developed economies (Osabohien et al., 2021a; Adegboye et al., 2020a; Asiedu, 2003). This inflow of economic goods can be referred to as Foreign Direct Investment (FDI). It is the decision of a government or an organisation to acquire a business inform of full ownership or part ownership of business concerns in countries other than their own (Adegboye et al., 2020b). This can assume the form of fresh set-up or acquiring existing ones. Investments such as this enables investors spread investment reach to enterprises outside their countries of origin (Asiedu, 2003a; Osabohien et al., 2020).

FDI is considered crucial to economic development as it is known to provide non-debt servicing foreign exchange, create employment, enhanced foreign relations, influence technology transfer, imitation, and licensing agreement and also enhance trade openness (Alfaro, 2006 ; Asiedu, 2013; Forster \& Toth, 2015; Osabohien et al., 2020; Matthew et al., 2021). Factors such as higher level of openness, economies with better infrastructures, depreciated local currency among others, have been found to attract FDI, especially in Sub-Saharan Africa [SSA] (Jaiblai \& Shenai, 2019; Eiji, 2017; Osabohien et al., 2020). Trade openness refers to condition of free flow of trade without hindrances, occasioned by tariffs and other official barriers to trade. It can equally assume the form of reduced tariff regime. Developing countries adopt trade liberalisation to foster economic expansion and development (Adegboye et al., 2020a). Africa and its sub-regions have risen to the urgent demand for all-inclusive development of the continent by rectifying couple of continental and regional economic, trade and developmental integrations. For instance, The African Continental Free Trade Area (AfCFTA) saddled with the responsibility of engendering regional cooperation within the continent to ensure that the primary sector which is the main stay of her economies are positioned to compete effectively in the global market. Also, the New Partner- ship for African Development (NEPAD) was birthed to attract FDI into the continent to bridge annual resource gap of $\$ 564 \mathrm{~b}$ which is needed to achieve the eradication of abject poverty from Africa (Aderemi et al., 2021; Asiedu, 2003a). Virtually, all the regions of the continent have one form of Regional Economic Community (REC) or the other. The West African Sub region has the Economic Community of West African States (ECOWAS) as her own REC. ECOWAS was set up primarily to facilitate trade within the sub region by removing barriers to trade. FDI to the continent over the past 10 years has grown by $11 \%$ to US $\$ 46 \mathrm{~b}$. However, the West African sub-region witnessed a decline of $15 \%$ to US $\$ 9.6 \mathrm{~b}$, with Nigeria and Ghana topping the losers with $43 \%$ to US $\$ 2 \mathrm{~b}$ and $8 \%$ to US\$3b respectively (United Nations Conference on Trade and Development, 2019). This is irrespective of her richness in natural resources which has been spotted as one of the key influencers of FDI (Anyanwu \& Nadege, 2015). The continent is a net exporter of primary produce which are products of mining and agriculture. Agriculture not only forms bulk of her stock in trade, but also provides employment, food security and poverty alliveation (Osabuohien \& Efobi, 2011). To ensure that the region thrieves in agricltural trading, the ECOWAS Trade Liberalization Scheme (ETLS) and ECOWAS Regional Agricultural Program (ERAP) were established in 1990 and 1995 respectively. This is done with the intent to achieve among other things, Goal two of the Sustainable Development Goals, which aim to end hunger, achieve food security and improve nutrition and promote sustainable agriculture (Bamiro, 2018).

Consequent on the fact that scholars have over the years been delibrating on the healthiness or otherwise of trade openness and FDI in fostering agricultural performance in the West African subregion, they have however failed to align to a particular stand on this subject matter. This is not unconnected with variation in methodologies, variables, timeframe and other vital information 
used in such studies. Also, the side of the argument wether from the importing or exporting side, that is supply or demand side has also added to the differentials in study outcomes. Given the above background, this study contributes to the extant literature by examing the impact of trade openess and foreign direct investment on agricultural sector sustainability in African. The study adopt the panel data technique to explicate on this relationship for 37 countries in Africa, sourced from the Country Policy and Institutional Assessment (CPIA) and World Development Indicators (WDI) of the World Bank for the period 2005-2019. This study is divided into five sections. Following this introduction is literature review, Methodology,Presentation of findings and discussion, recommendations and conclusion in that order.

\section{Materials and Method}

In this section, the works most relevant to the study are briefly discussed and thereafter the data used for the analysis are described.

\subsection{Literature Review}

Studies have been carried out to examine the direction of the impact of trade openness and FDI on agricultural performance in the ECOWAS region. However, concerns about the opportunities, and otherwise of trade openness which is mostly anchored on liberalisation of trade and FDI on agricultural sector performance is not peculiar to ECOWAS subregion. This is because; scholars have raised concerns for and against the duo. To provide a valid discuss, this study undergoes empirical review of the literature under the following subtitles.

\subsection{Trade Openness and Agricultural Sector Sus- tainability}

Studies on the relationship between trade openness and agricultural sector performance have resulted in inclusive outcomes. For example, Sotamenou \& Nehgwelah, (2018) De Silva, Malaga, \& Johnson (2013); Potelwa, Lubinga, \& Ntashangase (2016), Laiprakobsup (2014) supported the argument that trade openness positively impacts on agricultural sector performance.

Using annual data for a period of 35 years, Sotamenou \& Nehgwelah (2018) applied the Fully Modified Ordinary Least Squares (FMOL) to examine the effect of trade openness on agricultural output in Cameroun. The result revealed among other things, that trade openness in Cameroun gave rise to free movement of agricultural products, thereby encouraging and increasing agricultural production. Similarly, in Ghana, Awunyo-Vitor \& Sackey (2018) employing the Error Correction Mechanism (ECM), Granger Causality test on secondary data on Ghana's agricultural sector and economic growth, found a proportional significant relationship between economic growth and FDI which was proxied for trade openness to agricultural sector. The study suggests flexible trade policies to attract more FDI. In another study, Potelwa, Lubinga, \&Ntashangase (2016) studied factors that influence the growth of South Africa's agricultural export, and affirms that agricultural export enhancement positively impacts on economic performance. Applying Gravity Model for data on export growth between 2001 and 2014, the study confirms that trade agreement positively impacts on agricultural performance in South Africa. In Asia, De Silva, Malaga, \& Johnson (2013) investigating the impact of trade liberalisation on agricultural performance in Sri Lanka, using data between 1960 - 2010, employing the OLS and Multiple regression method, found that trade openness leads to improvement in agricultural productivity in Sri Lanka. Also, that trade openness, interest rate, free trade agreements among other factors, are accountable for the growth in agricultural sector in Sri Linka. On the contrary, findings from Shobande (2019) indicates that trade openness has strong negative effect on the performance of agricultural export in selected West African Countries. Using OLS the Gravity Model on annual time-series data for periods between 1970 to 2016 , the study posits that export side of agriculture is not favoured by trade openness. It suggests the adoption of common currency to mitigate the varying exchange rates in the region as well as aggressive agricultural extension and research on economic efficiency in the agricultural sub-sector to enhance performance. Djokoto (2013) found a negative relationship between trade openness and agricultural output in the short-run, while the long-run indicates that there is no relationship between the variables. This followed the study on the correlation between openness and agricultural performance in Ghana, using a 14-year data and adopting the ARDL method of analysis. On the strength of the findings, the study recommends selective FDI in the agricultural sector to reduce its negative impact.

Miljkovic \& Shaik (2010), studied the impact of trade openness on the technical efficiency in U.S. agriculture and found that trade protectionism leads to decrease in agricultural import and so enhances technical efficiency in agriculture. The study strongly discourages trade openness in order to ensure sustained technical efficiency in agriculture for concerned countries. This they achieved using stochastic frontier analysis (SFA) with data from 1948 to 2006. However, a study by Nin Pratt, Diao, \& Bahta (2009), applying dichotomy between exporting and importing nations on agricultural output confirms that there is no direct benefit for importing nations, whereas countries with effective comparative advantage in exporting agricultural produce stands to benefit immensely. This revelation was a product of partial equilibrium analysis of 193 agricultural firms in 14 countries of South Africa. 
Trade protectionism and barriers have been said to be necessary for the protection and encouragement of infant industries, especially, agro-based industries in Least Developed Countries (LDCs) (Matsuyama, 2019; Bond et al., 2012). This argument was favoured by observations by Shobande et al., (2018a), Beyene (2014) that agricultural sector performance in Africa especially, the West African sub-region has underperformed owing to trade openness amongest other factors such as poor funding, neglect, knowledge gap within the sector (Guei \& Le Roux, 2019) submitted that these negative impacts are evident due to the failure of policy makers to study the terms of agreement before rectifying such agreements, stressing that selective trade bilateral agreements is key for the survival of the ECOWAS economies.

\subsection{Foreign Direct Investment and Agricultural Sector Performance}

It has been argued that trade openness does not impact on FDI (Alfaro, 2006). On the other hand, Osabohien et al. (2020) pointed that trade openness impact on FDI and employment level in Africa. Alfaro (2006) and Olokoyo (2012) pointed that the reason why trade openness does not impact on FDI is owing to the fact that many other key economic considerations such as the viability of the institutions of state, corruption, government involvement in business either encourage or discourage FDI. The ECOWAS subregion, and the agricultural sector has not been a favourable destination for FDI. This is because of security concerns and other factors earlier mentioned (Asiedu, 2013; Olokoyo, 2012; Posu, Soile, \&Sangosanya, 2021)

However, studies have confirmed that despite obvious concerns, the impact of FDI when finally attracted outweighs that of trade liberalization (Forster $\&$ Toth, 2015). This is due to many benefits accruable from FDI which includes increased access to global market, employment creation (Osabohien et al., 2021), technology transfers, manpower training, bridging of income gap, rich source of non interest foreign exchange, access to improved technology and market, improved skill set for improved quality control, enhanced international relations amongst others (Glick \& Hutchison, 2013; Asiedu, 2006; Alfaro, 2006). Nevertheless Krugman (1991) is of the view that the application of the principle of pareto optimality underscored these many benefits accruable from FDI.

In specific study by Oloyede (2014), employing time-series data spanning from 1981- 2012, using ADF test for stationarity and granger causality test confirms that FDI positively impacts agricultural performance both in the short run and long-run. The study maintained that for this to be sustained, an enabling environment has to be created by the political class. Edeh, Eze, \& Ugwuanyi (2020) in a study of the impact of FDI on agricultural sector in Nigeria established that there is a significant positive impact of FDI on agricultural sector. Having employed quarterly timeseries data for 37 years and using the tools of Autoregressive Distributed Lagged (ARDL) model, FMOLS and the Dynamic Ordinary Least Squares (DOLS), on the strength of their findings recommended the extension of the existing tax holidays for foreign investors from 3 to 6 years to attract more FDI in necessary.

Studying the effect of FDI on agricultural sector performance in Nigeria, using data from the Central Bank of Nigeria (CBN) for period 1986-2015, and applying Augmented Dickey Fuller (ADF), Johansen test and ECM, Akinwale, Adekunle, \& Obagunwa (2018) found that FDI and bank credit had direct positive significant effect on agricultural performance in Nigeria. The study recommends adequate provision of infrastructure especially in the rural areas to encourage the flow of FDI. Also, Agba, Adewara, Nwanji, Yusuf, Adzor, \& Abbah, (2018) examine the impact of FDI on agricultural performance in Nigeria, and found a positive, but insignificant effect of FDI on agricultural sector performance in the short-run and a significant positive effect during the long-run. The study suggests stabilisation of exchange and interest rate in order to attract foreign investors.

Investigating the impact of FDI on general economic growth (Mahmoud, 2015) using quarterly data from 1976 to 1995 which was evaluated using multiple regression model, OLS, unit root test and granger causality test found that a significant and positive relationship exists between FDI and economic growth. It advocates for policies to reduce government involvement in business and that will attract more FDI. This position has been confirmed by Gherghina, Simioneseu and Hudea (2019); Bleaney \& Wakelin (2002); Abdul \&Nazia (2020); Olayiwola, Osabuohien, Okodua, \& Ola-David (2015).

In contrast, numerous studies have found negative effects of FDI on agricultural sector performance, as well as the general economic wellbeing of the country. Akinlo, (2004) examined the impact of FDI on economic growth in Nigeria using data spanning between 1970 - 2001 found that FDI has little or no impact on enhancing economic growth in Nigeria. Using ECM, it confirmed that FDI did not favour the extractive industry which agriculture is part of as much as it favoured the manufacturing industry. Rather labour force and human capital advancement positively impacted the extractive industry. It therefore suggests expansion of labour force and human capital development to ensure sustainable growth of the extractive industry. This position was revalidated in a recent study by Posu, Soile, \& Sangosanya (2021) Foreign direct investment and Nigerian economic growth: A Sectoral Analysis. The study which aims at uncovering the individualised impact of FDI on various sectors of the country's economy employing time series data from 1970-2003 and 
adopting OLS method of analysis found that FDI flows was not significant in the agricultural sector as it was in other sectors such as mining, communication and transportation.

Iddrisu, Immurana, \& Halidu (2015) in an empirical study of the impact of FDI on agricultural performance in Ghana carried out with data from 19802013. The study applied the Johansen cointegration test, found that FDI impacted agriculture in Ghana negatively in the long run, while the short run saw positive impact. The study therefore recommended stabilisation of the local currency as well as Ghanaian authority harnessing trade relation to ensure that FDI flows into the country is not toxic. Convincingly, very many empirical works have studied the individual as well as joint impacts of trade liberalisation and FDI on agricultural performance and by extension economic outcomes of various economies. But no consensus has been reached as to the exact direction of the impacts of these variables or the magnitude of such impacts. These variations can be explained by the different dataset, methodology, time-frame and geographical consideration adopted for these studies. It is then the desire of this work to provide insight into the joint impact of foreign direct investment and trade openness on agricultural sector performance in West African sub-region, using the 2SLS regression.

\subsection{Model Specification and Estimation Techniques} The study employs three techniques to achieve its objectives. The methods are; The Pooled Ordinary Least Squares (Pooled OLS), the Fixed Effects and the systems Generalised Method of Moments (GMM). Hence, following the study by Anser et al., (2021), Osabohien et al., (2021a) and Nhamo and Mukonza, (2020), the Pooled OLS and fixed model can be expressed as (equation 3 )

$l S A_{i t}=b_{0}+b_{1} l F D I_{i t}+b_{2} l T O P_{i t}+b_{3} l x_{\mathrm{it}}^{\prime}+e_{i t}$

Where, SA is sustainable agriculture (proxied by agriculture value added), with $b_{0}$ as the constant term, FDI captures Foreign direct investment, TOP, measures trade openness, $\mathrm{X}^{\prime}{ }_{\text {it }}$ is a vector of control variables such arable land, social protection and gross fixed capital formation. Equation (1) is estimated using the Pooled OLS and fixed effect regression. Before deciding on the use of fixed effect, the Hausman test was conducted.

In Pooled OLS, the individually specific effects are not taken into consideration. This is as a result of a lot of basic assumptions like orthogonality of the white noise are violated. However, the Random effects resolve this issue by executing an individual specify intercept in the model, which is expected to be random, which may lead to exogeneity. This verified with the Hausman-Test.
The results from the Hausman test showed that the fixed effect is preferred to the random effect analysis. The Hausman test result for the benchmark regression is $\chi 2=11.35(\mathrm{p}=0.0781)$, showing that the assumption that a model using random effects is preferable is clearly rejected. However, given the fact that the Pooled OLS and Fixed effect analysis may have some iota of endogeneity, the Generalised Method of Moments (GMM) is chosen. This is because, unlike the Pooled OLS and fixed effects, in the presence of endogeneity, it produces the best consistent estimates (Arellano \& Bond, 1991; Wooldridge, 2010). Following literature such as Anser et al., (2021); Baltagi (2008), the GMM model is specified in equation (2)

$l S A_{i t}=b_{0}+\vartheta l S A_{i t-1}+b_{1} l F D I_{i t}+b_{2} l T O P_{i t}+b_{3} l \mathbf{x}_{\mathrm{it}}^{\prime}+e_{i t}(2)$

Where, $I S A_{i t}$ measures agricultural sustainability for country $i(i=1,2 \ldots, N)$ at time $t(t=2,3, \ldots, T), b_{0}$ is the constant term, $S A_{i t-1}$ is the lagged dependent variable, with its coefficient $\vartheta, F D I_{i t}$ is foreign direct investment with its coefficient, $b_{1}, l T O P_{i t}$ is trade openness, with coefficient $b_{2}, \mathbf{X}_{\text {it }}$ covariate of the independent variables with the coefficient $b_{3}\left(b_{3}=\right.$ $1,2,3 \ldots N)$. To handle the problem of endogeneity, the study applied the system GMM. The study treats the endogeneity problem by using a two-step system GMM for the estimation of dynamic unbalanced panel data. For the case with a strong endogeneity,

\subsection{Data Sources and Description of Variables}

The study engaged a panel data obtained from the World Development Indicators (WDI), and Country policy and Institutional Assessment (CPIA) for a period ranging from 2005 to 2018, with 37 African countries listed in International Development Association (IDA) of the World Bank.

The variables used for the analysis are; agricultural sustainability (measured by food agricultural value added), social protection (captured by overall social protection coverage), arable land (hectare), employment in agriculture (\% of total employment); trade openness ( $\%$ of the GDP); gross fixed capital formation ( $\%$ of the GDP). The variables and their respective measurements are presented in Table 1.

\section{Results and Discussion}

This section of the study presents the results obtained from the estimated model and discusses it. The analyses begin with the summary statistics of the variables, which is presented in the next section.

\subsection{Summary Statistics}

We examined the features of the variable through the descriptive analysis which shows the summary statistics of the variables and their measures. This subsection indicates the statistical analysis of the variables used in the study-SA, Arbland, SOP, Agric E, 
Table 1. Variables, Measurement and Sources, source: Authors' compilation

\begin{tabular}{|c|c|c|c|c|}
\hline Symbol & Variable Name & Measurement & Source & Expectations \\
\hline SA & Sustainable Agriculture & Value added per worker & WD & $\begin{array}{l}\text { Not } \\
\text { Applicable }\end{array}$ \\
\hline GFCF & Gross fixed capital formation & It is essentially net investment (\% of the GDP) & WDI & Positive \\
\hline SOP & Social Protection & $\begin{array}{l}\text { policies for social coverage (scale: } 1=\text { low to } \\
6=\text { high) }\end{array}$ & CPIA & Positive \\
\hline Arbland & Arable Land & Hectare & WDI & Positive \\
\hline FDI & Foreign direct investment & $\begin{array}{l}\text { Foreign direct investment, net inflows (\% of the } \\
\text { GDP) }\end{array}$ & WDI & Positive \\
\hline TOP & Trade openness & $\begin{array}{l}\text { Summation of export receipts and import expendi- } \\
\text { ture divided by gross domestic products }\end{array}$ & WDI & Positive \\
\hline Agric E & Agricultural employment & $\begin{array}{l}\text { Employment in agriculture (\% of total employ- } \\
\text { ment) }\end{array}$ & WDI & Positive \\
\hline
\end{tabular}

Note: CPIA means country policy and institutional assessment, FAO means Food and Agricultural Organisation and WDI means World Development Indicators.

Table 2. Descriptive statistics of the variables, source: Authors'

\begin{tabular}{|l|l|l|l|l|}
\hline Variables & Mean & Std. Dev. & Min & Max \\
\hline Sustainable Agriculture & 1417.6 & 1284.22 & 196.08 & 5950.56 \\
\hline Arable land (hectare) & 5035188 & 6610136 & 1000 & $3.70 \mathrm{e}+07$ \\
\hline Social Protection & 3.221468 & .4830563 & 1.5 & 4.3 \\
\hline Agricultural employment & 55.47553 & 17.42301 & 10.6 & 90.3 \\
\hline Trade Openness & 69.54906 & 40.14656 & 16.66853 & 347.9965 \\
\hline Foreign direct investment & $-6.63 \mathrm{e}+08$ & $1.46 \mathrm{e}+09$ & $-1.08 \mathrm{e}+10$ & $8.75 \mathrm{e}+09$ \\
\hline Gross fixed capital formation & 22.26763 & 9.247498 & 2.0004 & 79.46179 \\
\hline
\end{tabular}

Table 3. Correlation Matrix, source: Authors'

\begin{tabular}{|l|l|l|l|l|l|l|l|}
\hline Variables & SA & Arbland & SOP & AgricE & TOP & FDI & GFCF \\
\hline SA & 1.0000 & & & & & & \\
\hline Arbland & 0.3148 & 1.0000 & & & & & \\
\hline SOP & -0.0106 & 0.0435 & 1.0000 & & & & \\
\hline AgricE & -0.7129 & 0.0523 & 0.0398 & 1.0000 & & & \\
\hline TOP & -0.1619 & -0.3989 & -0.1215 & -0.2896 & 1.0000 & & \\
\hline FDI & -0.2092 & -0.5609 & -0.1679 & 0.0226 & 0.0573 & 1.0000 & \\
\hline GFCF & -0.0168 & 0.0046 & 0.2601 & -0.2172 & 0.4123 & -0.137 & 1.0000 \\
\hline
\end{tabular}

TOP, FDI and GFCF. It also presents the mean value which is the sum of all values in the group data divided by the number of observations, median is the middle value of each variable in the data set, standard deviation is the square root of the variance; minimum value is the lowest number in the set of data; maximum value is the highest number in the set of data, and the range is the difference between the maximum and minimum values, as presented in Table 2 .

Table 2 shows the summary statistics for each variable use in the analysis. Sustainable Agriculture has an average value of 1417.6, and its value ranged between 196.08 and 5950.56 during the study period (2000-2018). The result also showed that the dispersion of sustainable Agriculture around its mean value is 1284.22 . The average value of arable land is 5035188 and its value ranged between 1000 and $3.70 \mathrm{e}+07$. The average value of social protection is 3.221468 and it ranged between 1.5 and 4.3. The dispersion of social protection around its mean value is 6610136. The mean value of Agricultural employment is 55.47553, and it ranged between 10.6 and
90.3. The result showed that the dispersion of Agricultural employment is 0.4830563 ; this is an indication that the series is closely clustered around its mean value, Agricultural employment of the selected countries over the study period clustered around its mean values. The mean value for trade openness is 55.47553 which ranged between 10.6 and 90.3. The result also showed the dispersion of trade openness around its mean value was 17.42301. The average value of trade openness (TOP) during the years under review is 69.54906 and it ranges from 16.66853 and 347.9965 . The result also showed the dispersion of trade openness around the mean values was 40.14656. Foreign Direct Investment (FDI) has an average value of $-6.63 e+08$ and it ranged between $-1.08 \mathrm{e}+10$ and $8.75 \mathrm{e}+09$. The results also showed the dispersion of foreign Direct Investment and its mean value was $1.46 \mathrm{e}+09$. The average value of Gross Fixed Capital Formation (GFCF) during the study period was 22.26763 , and it ranged between 2.0004 and 79.46179. The result also showed the dispersion of GFCF around its mean value as 9.247498 . 
Table 4. Regression Results (Ln SA), source: Authors'

\begin{tabular}{|c|c|c|c|}
\hline Variable & \multicolumn{3}{|c|}{ Dependent Variable: Ln SA } \\
\hline Independent Variable & Pooled OLS & Fixed Effect & System GMM \\
\hline \multirow{2}{*}{$\operatorname{Ln} \mathrm{SA}(-1)$} & - & - & $0.3886^{*}$ \\
\hline & - & - & $(0.001)$ \\
\hline \multirow[t]{2}{*}{ Ln Arbland } & $-0.234 * *$ & -0.1081 & $0.197 *$ \\
\hline & $(-0.049)$ & $(0.523)$ & $(0.000)$ \\
\hline \multirow[t]{2}{*}{ Ln SOP } & -0.3182 & $0.5128 * *$ & $1.398^{*}$ \\
\hline & $(0.170)$ & $(0.039)$ & $(0.000)$ \\
\hline \multirow[t]{2}{*}{ Ln Agric E } & $-0.138 *$ & $-0.9418 *$ & -1.08 \\
\hline & $(0.000)$ & $(0.000)$ & $(0.000)$ \\
\hline \multirow[t]{2}{*}{ Ln TOP } & $-0.3146 * *$ & $-0.2503 *$ & -0.4307 \\
\hline & $(0.003)$ & $(0.026)$ & $(0.000)$ \\
\hline \multirow[t]{2}{*}{ Ln FDI } & -0.0004 & -0.0004 & -0.0029 \\
\hline & $(0.801)$ & $(0.792)$ & 0.002 \\
\hline \multirow[t]{2}{*}{ Ln GFCF } & -0.0224 & -0.0455 & $0.2513 *$ \\
\hline & $(0.627)$ & $(0.317)$ & $(0.000)$ \\
\hline \multirow[t]{2}{*}{ Constant } & $14.111 * *$ & $12.781^{*}$ & $5.357 *$ \\
\hline & $(0.000)$ & $(0.000)$ & $(0.000)$ \\
\hline R.sq. & 0.61 & 0.57 & - \\
\hline Groups/Obs. & $27 / 144$ & $27 / 144$ & $25 / 144$ \\
\hline Wald chi2(6) & $103.58 *$ & - & - \\
\hline \multirow[t]{3}{*}{ F test } & $103.58 *$ & $9.05^{*}$ & $-2.78 *$ \\
\hline & $(0.000)$ & $(0.000)$ & \\
\hline & & & $(0.005)$ \\
\hline \multirow[t]{2}{*}{ AR (1) } & & - & $-3.98 *$ \\
\hline & & - & $(0.000)$ \\
\hline \multirow[t]{2}{*}{$\mathrm{AR}(2)$} & & - & $(1.57)$ \\
\hline & & - & $(-0.115)$ \\
\hline \multicolumn{2}{|l|}{ Hansen test } & - & 0.6 \\
\hline & & - & $(-0.742)$ \\
\hline
\end{tabular}

Note: The p-values are in the parentis ( ), *,**, and ***, means that the coefficient is significant at $1 \%, 5 \%$ and $10 \%$ level respectively

The results of the correlation matrix presented in Table 3 showed that there is a very little correlation among the variables in the model. According to $\mathrm{Gu}-$ jarati (2009), if the pairwise correlation between two variables exceeds 0.8 , this indicates high level of multicollinearity. Hence, the overall results indicate absence of multicollinearity.

\subsection{Econometric Results}

The econometric result from random effects, pooled OLS and system GMM for the 31 Africa countries for the period (2005-2019) are shown in Table 4. The table contains the estimated parameter and the probability values obtained from the regression equation, in which sustainable Agriculture is the dependent variable. The system GMM proposed by Arellano and Bond's dynamic panel data estimator was used to investigate the impact of FDI and trade openness on sustainable Agriculture in Africa. The model is practically useful for linear functional relationship that is dynamic, in the case of missing data and simultaneity bias. Generally, GMM estimators are known to produce coefficients that are consistent and asymptotically normal. For robust discussion, we also estimated the traditional pooled estimator such as the random effects model and the pooled OLS. The exogenous variables employed comprise $\log$ of Arable land, log of SOP, Log of Agricultural employment, log of trade openness, log of foreign direct investment and log of gross fixed capital formation. The statistics from the Hausman (1978) using a fixed effects instead of a random effects model. The Hausman test result for the regression is $\chi^{2}$ $=17.25$ when $\mathrm{p}=0.0158$, that is the assumption that a model using random effects is rejected.

The estimates obtained from the fixed effect model are presented in Table 4. From the results as presented in Table 4, if all things are made to be equal, sustainable Agriculture will be equal $12.781 \%$. It shows that a $1 \%$ rise in SOP will cause agricultural development to rise by $0.5128 \%$. Also, a $1 \%$ in Agricultural employment will result in $0.9418 \%$ increase in sustainable Agricultural. Similarly, a $1 \%$ rise in trade openness will cause agricultural development to decline by $0.2503 \%$. The result also shows that a $1 \%$ rise in foreign direct investment will cause sustainable Agricultural to decline by $0.0004 \%$. Furthermore, a $1 \%$ rise in gross fixed capital formation will result in $0.0455 \%$ decline in sustainable Agricultural.

The system GMM result is presented in Table 4. The diagnostic tests are impressive. The Hansen test accepts the null hypothesis of valid research instruments. Furthermore, the first-order autocorrelation tests accept the presence of autocorrelation, while the second rejected it. The one time-lagged depend- 
ent is both positive and significant. This justifies the use of dynamic GMM in our analysis, and also indicates that sustainable Agriculture adjusts to changes in the explanatory variables with a gestation lag across the estimation structure.

The estimated parameters are presented in Table 4. The result showed that a $1 \%$ rise in foreign direct investment will cause sustainable Agriculture to decline $0.00294 \%$. This implies that FDI has not positively influence sustainable Agriculture. Similarly, trade openness has negative impact on sustainable Agriculture. A $1 \%$ rise in trade openness will cause sustainable Agriculture to decline by $0.43066 \%$. This finding is in conformity with the report made by Shobande (2019). This result is not surprising given that African is still a net importer of agricultural product and other non-Agricultural products. The result however contradicted the report made by Wamboye et al., (2016a, 2016b) in their study which advocated for free market and push strongly for the integration of Africa into the global financial system in order to attract foreign direct investment and achieve economic development.

The exogenous variables are also important in explaining the level of agricultural productivity among the 37 countries. Social protection has the potential to influence sustainable Agricultural; hence a $1 \%$ rise in social protection will cause agricultural development to rise by $1.3982 \%$. Gross fixed capital formation has positive impact on sustainable Agricultural hence a $1 \%$ increase in gross fixed capital formation will cause agricultural development to increase by $0.2513 \%$. Arable land has significant positive impact on sustainable Agricultural. For instance, a $1 \%$ rise in arable land will cause agricultural development to rise by $0.1970 \%$. Finally, sustainable Agricultural has significant negative impact on sustainable Agricultural. For instance, a 1\% rise in Agricultural employment will cause sustainable Agricultural to decline by $1.0804 \%$.

\section{Conclusions}

From the results of this study, it was found that foreign direct investment and trade openness have significant negative impact on sustainable Agriculture for countries of Africa for the period 2005-2019. This is contrary to experience in other developing countries in Asia, the likes of India, China, Iraq and Lebanon; where globalization by encouraging foreign direct investments positively influenced technology, infrastructural development enhance growth and improve living standard (Siddiqui, 2017). For the selected SSA countries, globalization may not have influence on sustainable Agriculture due to low absorption of low technology and infrastructure. The interaction between FDI and sustainable Agriculture on one hand, and sustainable Agricultural and trade openness on the other hand are negative, and hence explanation for low rate of sustainable Agriculture for the selected countries in the Africa region. The study recommends that, as globalization opportunities are being explored by countries of Africa, protective policies should be used to encourage inflow of foreign direct investments into the agricultural sector, and not only the extractive industry as it has been the case. This is evident from the negative interaction that exists between sustainable Agriculture and trade openness on one hand and with foreign direct investment on the other hand. The implementation of policies that will encourage foreign direct investment into the real sector and agricultural sector will invariably bring a turnaround in from the negative interactions. Foreign direct investments that transfer technology and skills to the agricultural sector should be encouraged. It is imperative to put in efforts to attract foreign direct investment into the region particularly this era where the COVID-19 pandemics have resulted in fall in domestic resources and affected most household income. It is only through foreign direct that the fall in domestic resources can be complemented.

\section{References}

1. ABDUL J., NAZIA B., 2020, Revisiting the link between trade openness and economic growth using Panel methods, Research Square: 1-21.

2. ABDUllaH R., ARIL V., 2014, Determinants of international financial integration of GCC Market in emerging market and the global economy, Academic Press, New York: 31.

3. ADEREMI T. A., OLANIPEKUN W. D., BAMIDELE A. G., HASSAN, C. O., OSABOHIEN, R., \& AZUH, D. E., 2021. Role of Agriculture in Poverty Reduction in Nigeria: An Implication for Sustainable Development Goals (SDGs), African Journal of Business and Economic Research, 2021(si1), 267280.

4. AGBA D., ADEWARA S., NWANJI T., YUSUF, M., ADZOR K., ABBAH B.,2018, Does foreign direct investment impact Agricultural output in Nigeria? an error correction modelling approach, Journal of Economics and Sustainable Development, 9(4): 111.

5. AKINLO A. E., 2004, Foreign direct investment and growth in Nigeria: an empirical investigation, Journal of Policy Modelling, 26(5): 627-639.

6. AKINWALE S., ADEKUNLE E., OBAGUNWA T., 2018, Foreign direct investment inflow and Agricultural Sector Productivity in Nigeria, Journal of Economics and Finance, 9(4): 12-19.

7. ALFARO L., 2006, How does foreign direct investment Promote economic growth? exploring the effects of financial markets on linkages, NBER Working Paper, No 12522.

8. ANOWOR O., UKWENI N., IKEME M., 2013, The Impact of trade liberalisation on Nigeria Agricultural Sector, Journal of Economics and Sustainable Development, 4(8):14-24. 
9. ANYANWU J, NADEGE P., 2015, What are the drivers of Foreign direct Investment into West Africa? an empirical investigation, African Development Review, 27(3): 199-215.

10. ASIEDU E., 2003a, Foreign direct investment in Africa: The role of government Policy, governance and Political instability, Mimeo, Department of Economics, University of Kansas: 1-13.

11. ASIEDU E., 2006, Foreign direct investment in Africa; the role of natural resources, market size, government Policy, institution and political stability, The World Economy, 29(1): 63-77.

12. ASIEDU E., 2013,Foreign direct investment, natural resources and institution, Working Paper on international growth centre.

13. AWUNYO-VICTOR D., SACKEYR., 2018, Agricultural Sector Foreign Direct Investment and Economic Growth in Ghana, Journal of Innovation and Enterprenuer, 7(15): 67-82.

14. BAMIRO O.A., 2018, Sustainable development goals and the Nigerian University System, the first public lecture by Centre of Excellence in Reproductive Health Innovation, University of Benin delivered in August, 2018.

15. BEYENE H., 2014, Trade integration and revealed comparative advantages of sub-Saharan Africa and Latin America \& Caribbean merchandise export, International Trade Journal, 28(5):411-441, DOI: $10.1080 / 08853908.2014 .952851$.

16. BLEANEY M., WAKELIN K., 2002, Efficiency, innovation and export, Oxford Bulletin of Economics,3-15, https://ssrn.com/abstract=312813.

17. BOND E., KAZUMICHI I., KAZUO N., 2012, The dynamic Heckscher-Ohlin Model: A diagrammatic Analysis, International Journal of Economic Theory, 8(2): 197-211,

DOI: $10.1111 /$ j.17427363.2012.00186.x.

18. CHINODA T. 2020, The nexus between financial inclusion, trade and economic growth in Africa, Transnational Corporation Review, 12(3):266-275, DOI: 10.1080/19186444.20201742065.

19. DE SILVA N., MALAGA J., JOHNSON J., 2003, Trade Liberalization effects on Agricultural Production Growth: The Case of Sri Lanka, Selected Paper Presented at the Southern Agricultural Economic Association (SAEA) annual meeting, https://ageconsearch.umnedu>finalpaper.SAEA.

20. DJOKOTO J., 2003, Openness and Agricultural Performance in Ghana, Journal of Science and Technology (Ghana), 33 (2):24-36, DOI: 10.4314 /just.v33i2.3.

21. EDEH C., EZE C., UGWUANYI S., 2020, Impact of Foreign Direct Investment on the Agriculture Sector in Nigeria (1981-2017),African Development Review, 32(4): 551-564.

22. EIJI F., 2018, What Does trade openness measure?, Oxford Bulletin of Economics and Statistics, 81(4):868-888, DOI: 10.1111/obes. 12275.

23. FORSTER M., TOTH I., 2015, Cross-Country evidence of the multiple causes of inequality changes in the OEDC Area, Handbook of Income Distribution, 2(2015):1729-1843,

DOI: 10.1016/B978-0-444-59429-7.00020-0.
24. GHERGHINA S., SIMIONESEUS L., HUDEA O,. 2019, Exploring foreign direct investment - economic growth nexus; empirical evidence from Central and Eastern European Countries, Sustainability, 11(19):1-33.

25. GLICK R., HUTCHISON M., 2013,The evidence and impact of financial globalization, Elsevier, New York.

26. 25. GUEI K, Le ROUX P., 2019, Trade openness and economic growth: evidence from the economic community of Western African States Region, Journal of Economic and Financial Sciences, 1(12): 1-9.

27. HASSINE N., ROBICAUD, V., DECALUWE B.,2010, Agricultural Trade Liberalization, Productivity gain and Poverty Alleviation: aGenerla Equilibrium Analysis, CIRPEE Working Paper, 10-22.

28. IDDRISU A., IMMURANA M., HALIDU B., 2015, The impact of foreign direct investment on the Performance of the Agricultural Sector in Ghana, International Journal of Academic Research in Business and Social Sciences, 5(7):240-259.

29. IMF, 1977, World Economic Outlook, International Monetary Fund, Washington.

30. JAIBLAI P, SHENAI V., 2019, The determinants of foreign direct investment in sub-Saharan Economies: A Study of data from 1990-2017, International Journal of Financial Studies, 7(3):1-28, 43.

31. KRUGMAN P., 1991. Increasing Return and Economic Growth, The Journal of Political Economy, 483-99.

32. LAIPRAKOBSUPT, 2014, Democracy, trade openness and Agricultural trade policy in Southeast Asian Countries, Japanese Journal of Political Science, 15(3): 465-484, DOI: 10.S146810991400019x.

33. LAWAL A., NWANJI T., ASALEYE A., AHMED A, 2016, Economic growth, financial development and trade openness in Nigeria: An application of the ARDL Bound testing approach,Cogent Economics Finance, DOI: $10.1080 \% 2 \mathrm{~F} 23322039.2016 .1258810$.

34. MAHMOUD L., 2015, An investigation of the impact of FDI on economic growth: A Case Study of Mauritania, International Journal of Economics and Management Science, 4(2):1-5.

35. MATTHEW O. A., KAYODE F., OSABOHIEN R., URHIE E., FASINA F. F., FOLARIN, E. M., EDAFE, O. D., 2021,. Business Climate, Infrastructure and Institutions in Nigeria: Implication for Foreign Direct Investment. African Journal of Business and Economic Research, 2021(si1), 303-321.

36. MATSUYAMA K., 2019, Engel's law in the global economy: demand-Induced Patterns of structural changes, structural changes, innovation and trade, Econometrica, 87(2): 497-528, DOI: 10.3982/ECTA13765.

37. MAZHIKEYEV A., EDWARD T., RIZOU M., 2015, Openness and Isolation: The Trade Performance of Former Soviet Central Asian Countries, International Business Review, 24(16):935- 947, DOI: 10.1016/j.ibusrev-2015.03.001.

38. MILJKOVIC D., SHAIK S., 2010, The Impact of Trade Openness on Technical Efficiency in U.S.Agriculture, Journal of International Agricultural Trade and Development, 7:1-13. 
39. NIN PRATT A., DIAO X., BAHTA Y., 2009., Should regional trade liberalization of Agriculture be a Policy Priority in Southern Africa? Agriculture and Food Policy Conference Paper, 1-21.

40. OLAYIWOLA K., OSABUOHIEN E., OKODUA H., OLA-DAVID O., 2015, Economic integration, trade facilitation and Agricultural export Performance in ECOWAS sub-region, Regional integration and trade in Africa, Macmillian, New York: 3146.

41. OLOKOYO F., 2012, Foreign direct investment and economic growth: a case of Nigeria, Bvimer's Journal of Management Research, 4(1): 1-30.

42. OLOYEDE B., 2014. Impact of foreign direct investment on Agricultural sector development in Nigeria (1981-2012), Kuwait Chapter Arabian Journal of Business and Mangement Review, 3(12):1424.

43. OSABOHIEN R., OSABUOHIEN E.S., KHANG M.K., NGUYEN D.P., 2021a, Agricultural trade, foreign direct investment and inclusive growth in developing countries: evidence from West Africa, Transnational Corporations Review, DOI: $10.1080 / 19186444.2021 .1936986$

44. OSABOHIEN R., ADELEYE,B.N., OSABUOHIEN E., 2021b, African growth and opportunity act and trade performance in Nigeria, Heliyon 7: e06410, DOI: 10.1016/j.heliyon.2021.e06410.

45. OSABUOHIEN E., EFOBI U., 2011, Trade outcomes in Africa's regional Economic Communities and Institutional Quality: Some Policy Prescriptions, Economic Insights, Trend and Challenges, LXIII(4): 19-32.

46. OSU S, SOILE L, SANGOSANYA A., 2021, Foreign direct investment and Nigerian economic growth: a sectoral analysis, Philippine Review of Economics, 44: 171-194.

47. POTELWA X, LUBINGA M., NTASHANGASE T, 2016, Factors that Influence the Growth of South Africa's Agricultural Export to World Market, European Scientific Journal, 12(34): 195-215.

48. SHOBANDE O., 2019, Effects of economic intergration on Agricultural export performance inselected West African Countries, Economies,7(3):1-14.

49. SHOBANDE O., EZENEKWU U., UZONWANNE M.,2018a, Revisiting economic integration in West Africa: a theoretical exposition, Journal of Economics and Social Thought, 5: 3-7.

50. SOTAMENOU J, NEHGWELAH G.,2018, Impact of free trade on Agriculture: evidence From Cameroun, Journal of Smart Economic Growth, 3(2): 5570 .

51. United Nations Conference on Trade and Development (UNCTAD), 2005, Rethinking the Role of FDI, Economic Development in Africa, Geneva: 53).

52. United Nations Conference on Trade and Development, 2019, Volume of FDI to West Africa in the Past 10 years, UN, New York. 